\title{
Nowatorski program nauczania i wychowania w Gimnazjum Wołyńskim, późniejszym Liceum w Krzemieńcu (1805-1831)
}

\author{
The modern education programme \\ of the Volhynia Gymnasium, \\ later Lyceum in Krzemieniec
}

(1805-1831)

\begin{tabular}{|c|c|}
\hline $\begin{array}{l}\text { Gimnazjum Wołyńskie w Krzemieńcu założył Tadeusz Czacki przy wy- } \\
\text { datnej pomocy i współpracy Hugona Kołłątaja. Rangę liceum szkoła } \\
\text { ta uzyskała w } 1819 \text { roku. Przez niespełna } 26 \text { lat istnienia wpisała się } \\
\text { w historię wschodnich ziem Rzeczypospolitej pod rosyjskim zaborem } \\
\text { oraz dzieje polskiej oświaty. Tadeusz Czacki miał być orędownikiem } \\
\text { spraw i organizacji szkolnictwa na powierzonym mu terenie, podno- } \\
\text { szqc poziom szkolnictwa i nauczania. Czacki zajmował się sprawami } \\
\text { formalnymi i organizacyinymi szkoły, a program opracował Kołłq- } \\
\text { taj, uwzględniajqc jego koncepcje. Program nauczania przewidziany } \\
\text { był na } 10 \text { lat - cztery jednoroczne klasy oraz trzy dwuletnie kur- } \\
\text { sy. Nacisk kładziono na naukę ięzyków obcych. Uczniowie otoczeni } \\
\text { byli opiekq wychowawczq w trosce o wysoki poziom moralny, nie }\end{array}$ & $\begin{array}{l}\text { SLOWA KLUCZOWE } \\
\text { Gimnazjum Wołyńskie } \\
\text { w Krzemieńcu, Liceum } \\
\text { Krzemienieckie, na- } \\
\text { uczanie, wychowanie, } \\
\text { tradycia } \\
\text { KEYWORDS } \\
\text { Volhynia Gymnasium, } \\
\text { Lyceum in Krzemieniec, } \\
\text { education, teaching, } \\
\text { tradition }\end{array}$ \\
\hline
\end{tabular}


tylko naukowy, przyszłych absolwentów. Podlegali oni szczegółowemu regulaminowi, nacisk kładziono na równość wszystkich uczniów niezależnie od ich statusu społecznego. Szkoła oferowała bogaty program nauczania, a także możliwość korzystania z nadobowiqzkowych zajęć. Absolwentów łączyło poczucie wspólnoty zwiq̨zane z tq̨ placówkq, kultywowane przez długie lata.

\section{ABSTRACT}

The Volhynia Gymnasium in Krzemieniec was founded by Tadeusz Czacki with considerable help from Hugon Kołłąaj. The school became a Lyceum in 1819 and during its less than 26 years of existence gained a permanent place in the history of the Polish Commonwealth's eastern territories annexed by Russia, as well as in the history of Polish education. Czacki was responsible for formal and organisation issues, while Kołłataj prepared the teaching programme on the basis of Czacki's ideas. The programme was designed for 10 years of education - four 1 -year courses plus three 2-year courses. Teaching foreign languages was a priority. The school paid close attention to students' moral advancement as well as the increase of their knowledge. Students followed a strict set of rules with emphasis on the equality of all students irrespective of their social status. The school offered a rich teaching programme as well as extracurricular activities. Graduates were bound by a sense of brotherhood developed at this school and cultivated their friendships for many years later.

\section{Wprowadzenie}

Gimnazjum Wołyńskie w Krzemieńcu założył w 1805 roku Tadeusz Czacki przy wydatnej współpracy i pomocy Hugona Kołłątaja. Rangę liceum szkoła ta uzyskała w 1819 roku. Przez niespełna 26 lat istnienia na trwałe wpisała się w historię wschodnich ziem Rzeczypospolitej pod rosyjskim zaborem i dzieje polskiej oświaty ${ }^{1}$.

Powstanie Gimnazjum Wołyńskiego umożliwił ukaz carski z dnia 24 stycznia 1803 roku, wprowadzający nowy system szkolny na

1 E. Danowska, Po upadku Liceum Krzemienieckiego (1805-1831). Polemiki i wspomnienia, „Annales Academiae Paedagogicae Cracoviensis”, Folia 57. Studia Historica VII (2008), s. 76. 
ziemiach polskich wchłoniętych przez Imperium Rosyjskie, aczkolwiek na podstawie dorobku Komisji Edukacji Narodowej (1773-1794)².

Tadeusz Czacki dnia 5 maja 1803 roku otrzymał nominację na wizytatora szkół guberni wołyńskiej, podolskiej i ukraińskiej. Stanowisko to zawdzięczał kuratorowi Wileńskiego Okręgu Naukowego księciu Adamowi Jerzemu Czartoryskiemu, który zaprotegował go u ministra oświecenia publicznego Piotra Zawadowskiego. Książę uważał Czackiego, słusznie zresztą, za człowieka rozumnego, energicznego i zaangażowanego w sprawy społeczne. $\mathrm{W}$ jego zamyśle miał on być orędownikiem spraw i organizacji szkolnictwa na powierzonym mu terenie, podnosząc poziom nauczania. Czacki, znany działacz polityczny w czasach szlacheckiej Rzeczypospolitej oraz autor wielu opracowań naukowych głównie z dziedziny historii prawa, nie ukrywał, że sprawy pedagogiki są mu obce, sam nie miał wykształcenia ani praktyki pedagogicznej. W powierzonej mu funkcji wizytatora kompetencje menadżerskie były niezbędne, a takie Czacki posiadał $^{3}$.

Tadeusz Czacki jako wizytator sumiennie wypełniał swoje obowiązki, nie ukrywając katastrofalnego poziomu nauczania w powierzonych jego opiece i nadzorowi szkołach. W liście z 19 lipca 1803 roku do Hugona Kołłątaja napisał: „Szkoły Zahorowskie są składem głupstwa, a Włodzimierskie przybytkiem nędzy. W pierwszym miejscu gramatyka Kopczyńskiego nie była znaną, w drugiem nauczyciel niemieckiego nie rozumiał najprostszej mowy i wyznał, że tylko w życiu całem przez dwa uczył się miesiące. [...] Nauki potrzebniejsze chcę mieć stosowne od szkoły głównej do parafialnych szkółek"4.

W liście z 8 września 1803 roku do rektora Uniwersytetu Wileńskiego Hieronima Stroynowskiego, Kołłątaj nie szczędził wyrazów

2 J. Chodakowska, Gimnazjum i Liceum Wotyńskie w Krzemieńcu (1805-1832), w: Krzemieniec. Ateny Juliusza Stowackiego, red. S. Makowski, Warszawa 2004, s. 9.

3 E. Danowska, Tadeusz Czacki 1765-1813. Na pograniczu epok i ziem, Kraków 2006, s. 234-235. Zob. też: A. Szmyt, Gimnazjum i Liceum Wotyńskie w Krzemieńcu w systemie ośriaty Wileńskiego Okregu Naukowego w latach 1805-1833, Olsztyn 2009, s. 77-96; R. Przybylski, Krzemieniec. Opowieść o rozsqdku zwyciężonych, Warszawa 2003, s. 36.

$4 \quad$ X. Hugona Kottataja korrespondencya listowna z Tadeuszem Czackim [...], wyd. F. Kojsiewicz, Kraków 1844, t. 1, s. 84-85. 
uznania dla Czackiego, któremu bardzo zależy na podniesieniu poziomu nauczania w szkołach. Nadmienił, że Czacki zamierza powołać do życia gimnazjum (na które już zaczął gromadzić fundusze) mogące być wzorem dla innych placówek. Przez cztery lata trwałaby w nim intensywna nauka języków obcych, arytmetyki, geografii i nauk moralnych. Natomiast w kolejnych latach nauki miałyby być wykładane: matematyka, logika, historia naturalna, chemia, fizyka, mechanika praktyczna, prawo, historia i literatura - przedmioty nauczane na uniwersytetach ${ }^{5}$.

\section{Poczq̨ti Gimnazjum Wołyńskiego}

Zrealizowanym marzeniem Czackiego było założenie w 1805 roku Gimnazjum Wołyńskiego w Krzemieńcu placówki nowoczesnej, o ambitnym programie nauczania i spełniającego wymogi swoich czasów. W prace przygotowawcze poprzedzające jego otwarcie gorliwie włączył się Hugo Kołłątaj sporządzając plany, notatki, spisując pomysły. Swymi koncepcjami dzielił się z Czackim w listach oraz w czasie wspólnych narad. Wszystko wskazuje na to, że Czacki nakreślił ogólny rys, jak ma wyglądać wzorowe gimnazjum, a Kołłątaj dopracowywał szczegóły, jako osoba posiadająca znaczne doświadczenie w reformowaniu oświaty ${ }^{6}$.

Społeczność Wołynia, dokonując darowizn na rzecz mającego powstać gimnazjum na ogół była zdania, że szkoła nie ma kształcić potencjalnych geniuszy, lecz rozumnych i światlych obywateli, dobrych gospodarzy niosących postęp, przygotowywać do życia publicznego, a absolwenci winni cechować się wysokim poziomem moralnym. Okazało się, że szkoła spełniła nie tylko te postulaty, ale też umożliwiła zdobycie wszechstronnych wiadomości ze wszystkich dziedzin nauki i życia praktycznego oraz rozwój talentów?

5 Tamże, t. 1, s. 227-228.

6 Tamże, t. 1, s. 239 i nast. Zob. E. Danowska, Tadeusz Czacki i Hugo Kottqtaj. Kulisy wspótpracy przy tworzeniu Gimnazjum Wotyńskiego w Krzemieñcu, w: „Ateny Wotyńskie” - między bistoriq a wspótczesnościa, red. A. Szmyt i H. Stroński, Olsztyn-Krzemieniec 2015, s. 65-76.

7 A. Szmyt, Gimnazjum i Liceum Wotyńskie w Krzemieńcu w systemie oświaty Wileńskiego Okręgu Naukowego w latach 1805-1833, dz. cyt., s. 156-157. 


\section{Program nauczania}

Czacki i Kołłątaj w planowaniu programu nauczania w Gimnazjum Wołyńskim musieli respektować ogólne wytyczne znajdujące się w Ustawie dotyczącej oświaty z 19 maja 1803 roku, wydanej przez cara Aleksandra I. Według ustawy, nauka w każdym gimnazjum ma trwać co najmniej 6 lat i zatrudnionych ma być sześciu tzw. starszych nauczycieli, którzy wykładaliby fizykę, matematykę, nauki moralne, literaturę i język łaciński, łacińską i polską gramatykę, arytmetykę i geografię. Natomiast czterech młodszych nauczycieli nauczać ma m.in. języków obcych. Obydwaj twórcy przyszłego gimnazjum podkreślali, że łacina (nauczana według podręcznika Onufrego Kopczyńskiego) i greka to „drogie starożytnej literatury skarby”, język rosyjski jest niezbędny jako "mowa rządu” i narodu słowiańskiego, a francuski i niemiecki to języki „prawdziwie uczonych narodów". Gimnazjum miało zapewnić absolwentom solidne wykształcenie, przydatne w życiu społecznym. Tych wytycznych musieli przestrzegać Czacki i Kołłątaj przy tworzeniu gimnazjum wołyńskiego $^{8}$. Na czym mial polegać system nauczania w Gimnazjum Wołyńskim, Czacki podał do publicznej wiadomości już w grudniu 1803 roku$^{9}$.

Tradycją stało się publikowanie przed każdym kolejnym rokiem szkolnym broszury informującej zainteresowanych o systemie nauczania w Gimnazjum Wołyńskim, zakresie programowym każdego przedmiotu, godzinach odbywania się poszczególnych lekcji oraz podawano nazwiska wykładowców przedmiotów. Pierwsza broszura, wydana w 1805 roku, zatytułowana Wzór i porzqdek nauk które na lekcyach publicznych w Gimnazium Wotyńskiem od 1 października 1805 do ostatnich dni lipca 1806 dawane będq, była najobszerniejsza i najbardziej dokładna. Wydana w języku polskim, zawierała też równoległe tłumaczenie tekstu na język łaciński ${ }^{10}$.

$8 \quad$ X. Hugona Kottataja korrespondencya listowna z Tadeuszem Czackim [...], dz. cyt., t. 1, s. 298-308.

9 E. Danowska, Tadeusz Czacki 1765-1813. Na pograniczu epok i ziem, dz. cyt., s. 263.

10 Wzór i porzadek nauk które na lekcyach publicznych w Gymnazium Wotyńskiem od 1 pazdziernika do ostatnich dni lipca 1806 dawane będq. Prospectus et ordo studiorum in praelectionibus publicis in Gymnasio Volbyniensi a 1 octobris 1805 
Program nauczania opierał się w dużej mierze na założeniach i koncepcjach - jak już wspomniano - Komisji Edukacji Narodowej, które były wyrazem polskich tradycji i doświadczeń, a równocześnie wyrazem tendencji oświatowych Oświecenia. Zakres nauk był bogaty, wykraczający poza sugestie i zarządzenia oświatowych zwierzchników. Program dydaktyczny szkoły został rozłożony na dziesięć lat nauki - cztery jednoroczne klasy i trzy dwuletnie kursy, gdzie nauka odbywała się na wzór uniwersytecki ${ }^{11}$.

Hugo Kołłątaj po długich dyskusjach i rozważaniach z Tadeuszem Czackim, opracował Projekt urządzenia gimnazyum wotyńskiego, w mieście Jego Imperatorskiej Mości Krzemieńcu i wszystkich innych szkót w gubernii wotyńskiej zaprowadzić sie majacych, podany do najwyższego potwierdzenia od wizytatora nadzwyczajnego szkót trzech gubernij wotyńskiej, podolskiej i kijowskiej, co było podstawą do ubiegania się o stosowne zezwolenie potrzebne dla ustanowienia szkoły w Krzemieńcu ${ }^{12}$.

Celem twórców Gimnazjum Wołyńskiego było zaprowadzenie w tej placówce poszerzonego programu nauczania, opartego na kształceniu ogólnym, rozwijanie talentów i zdolności, ale też wdrożeniu uczniów do praktycznych umiejętności. Miał on wychować młodzież w poszanowaniu pracy i nauki, a także odpowiadać zapotrzebowaniom regionu przygotowując ją do życia społecznego ${ }^{13}$.

W liście z 19 lutego 1804 roku Hugo Kołłątaj donosił Czackiemu, że Ignacy Potocki, były działacz KEN i przewodniczący Towarzystwa do Ksiąg Elementarnych, zapoznawszy się z programem

ad ultimo Julii 1806 tradendorum, b. m. i r. wyd., nlb. Z kolejno wydawanych publikacji - już mniej obszernych (np. w 1809 r. - 8 str.) - wynika, że rok szkolny rozpoczynał się 1 września, natomiast data zakończenia na ogół nie była stała. Drukowano broszury zapewne w najbliższej drukarni w Poczajowie, a od 1811 roku w Krzemieńcu. Wtedy bowiem rozpoczęła działalność przyszkolna drukarnia, zob. E. Danowska, Drukarnia i ksiegarnia przyszkolna Gimnazjum Wotyńskiego i Liceum Krzemienieckiego (1811-1832), w: Dziatalnośc instytucji wydawniczych na rzecz oświaty i edukacji w XIX i XX wieku, pod red. I. Michalskiej i G. Michalskiego, Łódź 2014, s. 221-230.

11 A. Szmyt, Gimnazjum i Liceum Wotyńskie w Krzemieńcu w systemie oświaty Wileńskiego Okregu Naukowego w latach 1805-1833, dz. cyt., s. 156-157.

12 X. Hugona Kottataja korrespondencya listowna z Tadeuszem Czackim [...], dz. cyt., t. 2, s. 1-148.

13 J. Chodakowska, Gimnazjum i Liceum Wotyńskie w Krzemieńcu (1805-1832), dz. cyt., s. 11-12. 
nauczania gimnazjum w Krzemieńcu, zarzucał obciążenie młodzieży nauką aż pięciu języków obcych, uważając to za zbyteczne novum. Kołłątaj zaś obstawał przy poglądzie, że co prawda: „nauka wielu języków zabiera wiele czasu i jest najnieprzyjemniejsza ze wszystkich, których się w szkole uczyć trzeba", ale każdy z tych języków z różnych przyczyn jest przydatny ${ }^{14}$.

Z kolei w liście z 22 września 1805 roku Kołłątaj napisał do Czackiego: „wychowanie publiczne musi zaczynać się musi od nauki języków; bo wiek ten najbardziej potrzebuje ćwiczenia pamięci, wszelako szczególniejsza na to dana jest baczność, aby młodzi uczniowie, ćwicząc pamięć wprawiali się oraz od pierwszych początków $\mathrm{w}$ ćwiczenie reflexyi nawykali do dobrych obyczajów ${ }^{15}$.

W dalszym ciągu swego listu uzasadniał konieczność nauczania każdego z przedmiotów zaplanowanych w Gimnazjum Wołyńskimm ${ }^{16}$.

Otwarcie Gimnazjum Wołyńskiego w Krzemieńcu odbyło się 1 października 1805 roku. Rozpoczęcie pierwszego roku szkolnego odbyło się nader uroczyście ${ }^{17}$.

Sporządzony został, zapewne przez Hugona Kołłątaja, Wzór i porzqdek nauk, które będq dawane w Imperatorskiem Wotyńskiem Gimnazyum od dnia 1 października 1805 do dnia 31 lipca 1806 roku w Krzemieńcu. Język polski i łaciński stanowiły połączony przedmiot, który miał być nauczany przez cztery lata. Nacisk kładziono przede wszystkim na gramatykę języków. Zakres nauczania języka rosyjskiego obejmował naukę współczesnego języka jak i staro-cerkiewno-słowiańskiego. Uczniowie mieli opanować prawidła języka, gramatykę, właściwą konstrukcję zdania, składnię i akcent, czytanie ze zrozumieniem, pisownię liter i ortografię oraz tłumaczenie wybranych tekstów rosyjskich autorów. Uczeń czwartej klasy, kończącej nauczanie tego języka musiał sprawnie dokonywać przekładów z rosyjskiego na polski i odwrotnie - prozy i poezji. Co ciekawe, nauczyciel języka rosyjskiego (Antoni Strzelecki) wykładał także arytmetykę. Do nauczania tego przedmiotu zaliczało

14 X. Hugona Kottataja korrespondencya listowna z Tadeuszem Czackim [...], dz. cyt., t. 2, s. 357-358.

15 Tamże, t. 3, s. 276.

16 Tamże, t. 3, s. 278-279.

17 E. Danowska, Tadeusz Czacki 1765-1813. Na pograniczu epok i ziem, dz. cyt., s. 279-284. 
się powtórzenie opanowania czterech podstawowych działań matematycznych, nauka działania na ułamkach zwykłych i dziesiętnych czy obliczania procentów. Uczeń kończący naukę algebry powinien także umieć podnosić liczby do kwadratu i sześcianu oraz wyższych potęg, wyciągać pierwiastki, być zapoznanym z logarytmami. Kolejny nauczyciel - Paweł Jarkowski miał nauczać języka francuskiego i nauki moralnej. Zakres umiejętności nabytych w zakresie nauczania tego języka był także szczegółowo określony. Co do nauki moralnej: to "traktować będzie o wzajemnych uczniów i nauczycielów, służących i panów obowiązkach", a także wszelkich obowiązkach i powinnościach uczciwego człowieka żyjącego w społeczeństwie, jak być człowiekiem przyzwoitym i cnotliwym. Inny nauczyciel miał nauczać języka niemieckiego i geografii, a Wojciech Jarkowski był wyznaczony jako wykładowca geometrii teoretycznej, trygonometrii płaskiej i geometrii praktycznej ${ }^{18}$.

Kołłątaj szczegółowo opracował plan lekcji w czterech początkowych klasach i wszystko wskazuje na to, że zazwyczaj się go w krzemienieckiej placówce trzymano. I tak, na przykład klasa pierwsza w poniedziałek w godzinach od 8.00 do 10.00 miała lekcje języka rosyjskiego, a od 2.00 do 4.00 po południu odbywała się lekcja języka polskiego i łacińskiego. We wtorek od 8.00 do 9.00 była arytmetyka, potem godzina j. polskiego i łacińskiego, a po południu czas wolny. W środę od 8.00 do 10.00 odbywała się lekcja języka francuskiego, a po południu (od 2.00. do 4.00) języka niemieckiego. W czwartek od 8.00 do 9.00 była nauka moralna, od 9.00 do 10.00 - jeografia powszechna. Popołudnie było wolne od nauki. W piątek pierwsza klasa od 8.00 do 10.00 uczyła się języka rosyjskiego, od 2.00 do 4.00 - języka polskiego i łacińskiego. W sobotę od 8.00 do 10.00 była lekcja francuskiego, a od 2.00 do 4.00 języka niemieckiego.

Wymienione tu zostały przedmioty rozpoczęte w pierwszej klasie, takież same i w tym samym wymiarze godzinowym były kontynuowane w klasie drugie, trzeciej i czwartej. W programie przeważało nauczanie języków: polskiego wraz z łaciną, rosyjskiego, niemieckiego i francuskiego, a poza nimi wykładano jeszcze arytmetykę, naukę

18 X. Hugona Kottataja korrespondencya listowna z Tadeuszem Czackim [...], dz. cyt., t. 3, s. 212-225. Podstawowe podręczniki do nauczania poszczególnych przedmiotów w Gimnazjum Wołyńskim podaje Alojzy Osiński w liście do Hugona Kołłątaja z 3 maja 1806 roku, zob. tamże, t. 4, s. 120. 
moralną i geografię powszechną. Popołudnia we wtorki i czwartki jak już wspomniano - były wolne dla każdej z klas ${ }^{19}$.

$\mathrm{Na}$ marginesie można dodać, że w 1808 roku rozpoczął się spór między rektorem Uniwersytetu Wileńskiego, pełniącym rolę zwierzchnika nad szkolnictwem średnim Wileńskiego Okręgu Naukowego a Tadeuszem Czackim. Jedną z przyczyn był zamiar Czackiego, pełniącego funkcję wizytatora, zaprowadzenia systemu nauczania istniejącego w Gimnazjum Wołyńskim (cztery klasy, a po nich trzy dwuletnie kursy) także w innych gimnazjach Okręgu. Śniadecki, podobnie jak jego poprzednik Hieronim Stroynowski, mimo zastrzeżeń zaakceptował system nauczania w Krzemieńcu, lecz upowszechniać go nie zezwolit. Nie miał przekonania do przeciążania uczniów nauczaniem zbyt wielu języków obcych kosztem innych przedmiotów („sposobienia na papugi”), wykorzystywaniu innych podręczników niż preferowane przez Uniwersytet. Zarzucał, że dziesięcioletni program kształcenia jest zbyt kosztowny, a także, że uczniom przekazuje się materiał niczym dorosłym, np. nauczanie matematyki wyższej w gimnazjum nie jest potrzebne. Wspomnieć można, że „system krzemieniecki”, za namową Czackiego, samowolnie zastosowali pijarzy w swej szkole powiatowej w Międzyrzeczu Koreckim. „Zbuntowani” pijarzy nie ulegli naciskom Uniwersytetu względem wycofania się z przystąpienia do „krzemienieckiej schizmy", a między Czackim i rektorem Śniadeckim przez pewien czas zapanowały oziębłe stosunki ${ }^{20}$.

Powróćmy do systemu nauczania w Gimnazjum Wołyńskim. Rozplanowany został również plan lekcji dla trzech dwuletnich kursów. W ciągu pierwszego dwuletniego kursu wykładano język grecki, matematykę i historię powszechną. Lekcje odbywały się od godziny 8.00 do 4.00 po południu, $z$ dwugodzinną przerwą między 11.00 a 1.00. Wyjątek stanowily wtorki i czwartki, gdzie lekcje kończyły się o 2.00 dla każdego z trzech kursów. Innych przedmiotów nauczano

19 Tamże, t. 2, s. 28-29; P. Bryła, Organizacya gimnazyum Krzemienieckiego, w: Sprawozdanie Dyrektora c.k. Gimnazyum św. Jacka w Krakowie za rok szkolny 1889, Kraków 1889, s. 10-23.

20 E. Danowska, Tadeusz Czacki 1765-1813. Na pograniczu epok i ziem, dz. cyt., s. 294-295. Zob. też: D. Beauvois, Szkolnictwo polskie na ziemiach litewsko-ruskich 1803-1832, t. II Szkoty podstawowe i średnie, Lublin 1991, s. 204-211. 
na drugim dwuletnim kursie. Była to fizyka, mechanika praktyczna i prawo. Na trzecim dwuletnim kursie wykładano historię naturalną i chemię, gramatykę powszechną, bibliografię i literaturę ${ }^{21}$.

Do przedmiotów dodatkowych, czyli nadobowiązkowych, zaliczono matematykę wyższą wykładaną przez dyrektora szkoły Józefa Czecha, mechanikę praktyczną wykładaną przez Franciszka Zaliwskiego, a także język grecki ${ }^{22}$.

Tadeusz Czacki, zapoznawszy się z koncepcjami rozkładu lekcji i planem dnia gimnazjalistów opracowanym przez Kołłątaja, sugerował, by program nauczania w wyższych klasach poszerzyć o ogrodnictwo i muzykę. 3 listopada 1803 roku napisał do niego: „Czytałem i odczytałem tablice godzin uczniów. Zdaje mi się, że mało jest naznaczonych godzin do uczenia się. Ta młodzież będzie próżnować. Nie mam w tej materyi doświadczenia, moje mniemanie tylko wykładam"23.

Kołłątaj odpisując Czackiemu napomknął, że ten przecież odbierał tylko edukację domową, więc powinien zaufać jego doświadczeniu, że w młodszych klasach nie powinno być więcej nauki niż dwie godziny przed południem i dwie po południu. Dzieci nie będą próżnowały, odrabiając zadania domowe, a należy też zapewnić wolny czas na zabawy i spacery potrzebne dla zdrowia ${ }^{24}$.

Każdy z nauczycieli wykładających dany przedmiot był zobowiązany do przedstawienia programu lekcji oraz wykazu literatury, którą będzie wykorzystywał. W liście do Czackiego z 8 sierpnia 1805 roku, czyli jeszcze zanim gimnazjum zostało otwarte, Kołłątaj wspominał, że napisał taki program dla Antoniego Jarkowskiego i Karola

21 X. Hugona Kottataja korrespondencya listowna z Tadeuszem Czackim [...], dz. cyt., t. 2, s. 32-33. Szczególowy plan nauczania historii i geografii powszechnej, zob. tamże, t. 4, s. 1-69 oraz rozkład materiału, zob. tamże, t. 4, s. $160-165$.

22 Tamże, t. 3, s. 226-234. Wykaz nauczycieli w Gimnazjum, późniejszym Liceum podaje absolwent szkoły Adam Słowikowski, zob. A. Słowikowski, Wspomnienia szkoty krzemienieckiej, za: Krzemieniec. Ateny Juliusza Stowackiego, pod red. S. Makowskiego, Warszawa 2004, s. 472-474. Biogramy m. in. krzemienieckich nauczycieli zamieszcza W. Piotrowski, Stownik Krzemieńczan 1805-1832, Piotrków Trybunalski 2005.

23 X. Hugona Kottataja korrespondencya listowna z Tadeuszem Czackim [...], dz. cyt., t. 1, s. 370-371.

24 Tamże, t. 1, s. 372-373. 
Mirowskiego, którzy prosili go o pomoc. Oczekuje natomiast nadesłania programów przez innych nauczycieli ${ }^{25}$.

\section{Szkolna codzienność}

Do Gimnazjum Wołyńskiego wstępowali chłopcy po ukończonej edukacji domowej lub szkolnej, udokumentowanej świadectwem, mający 8-10 lat. Mury tej szkoły opuszczali ukończywszy pełny cykl kształcenia, w wieku 18-20 lat ${ }^{26}$. Kształcić mógł się każdy bez względu na status materialny, bowiem najubożsi mogli korzystać ze stypendiów umożliwiających pobyt w Krzemieńcu. Chociaż gimnazjum było otwarte dla chłopców każdego stanu, to uczęszczali doń jednak w większości szlacheccy synowie. Nauki pobierali potomkowie arystokratycznych rodów, ziemiaństwa, bogatej i biednej szlachty, synowie mieszczan i chłopów, a nawet nieliczni Izraelici. Spoza szlachty pochodziło szacunkowo około 12\% uczniów. Ideą twórców szkoły było przestrzeganie godności ucznia i niwelowanie różnic społecznych - wszyscy uczniowie byli traktowani jednakowo, co świadczy też o nowoczesności tej placówki ${ }^{27}$.

Wspomnieć można o fakcie, który niekiedy bawi współczesnych nam historyków szkolnictwa, że Kołłątaj okazał się niebywałym pedantem, w szczegółach podając, co powinien ze sobą zabrać chłopiec udający się do szkoły w Krzemieńcu. Wyszczególnił praktyczne przedmioty, takie jak wyznaczoną ilość mydła, szuwaksu, igieł, nici, papieru, przyborów do pisania ${ }^{28}$.

$\mathrm{Na}$ bazie ukończonego Gimnazjum Czacki i Kołłątaj zaplanowali dalsze możliwości kształcenia w krzemienieckiej placówce. Otwarto czteroletni kurs dla nauczycieli szkół parafialnych, przewidujący takie

25 Tamże, t. 3, s. 145-146, 243-244. Zob. też: H. Kołłątaj, Rada dla Imć Pana Mirowskiego, jakim sposobem najpożyteczniej dokonywać można historyq i jeografiq w szkotach publicznych, tamże, t. 3, s. 171-194.

26 P. Bryła, Organizacya gimnazyum Krzemienieckiego, w: Sprawozdanie Dyrektora c.k. Gimnazyum św. Jacka w Krakowie za rok szkolny 1889, dz. cyt., s. 26.

27 C. Kisiel-Dorohinicka, W stronę Krzemieńca. W poszukiwaniu inspiracji dla wychowania w czasach wspótczesnych, w: „Ateny Wotyńskie” - między historia a wspótczesnościa, pod red. A. Szmyta i H. Strońskiego, Olsztyn-Krzemieniec 2015, s. 291, 294, 303-304; J. Chodakowska, Gimnazjum i Liceum Wotyńskie w Krzemieńcu (1805-1832), dz. cyt., s. 21.

28 R. Przybylski, Krzemieniec. Opowieść o rozsądku zwyciężonych, dz. cyt., s. 41-42. 
przedmioty, jak: język rosyjski, język polski i łaciński, muzyka wokalna, muzyka instrumentalna, arytmetyka, ogrodnictwo i rolnictwo, geografia powszechna, nauka moralna. Nauczanie tych przedmiotów kontynuowano przez cztery lata ${ }^{29}$.

Powstały także trzyletnie szkoły na bazie ukończonego Gimnazjum: mechaników praktycznych (reskrypt carski z 17 lipca 1807 r.) i geometrów, czyli mierniczych rządowych (reskrypt z 27 lipca 1807 r.). W kształceniu kładziono nacisk głównie na umiejętności praktyczne, ale wykładano też m.in. geometrię, algebrę, mechanikę, hydraulikę, trygonometrię, topografię, prawo krajowe i urzędową korespondencję. Nie zostały zrealizowane analogiczne projekty trzyletnich szkół dla cyrulików, chirurgów, akuszerek, weterynarzy, ogrodników, a także guwernantek ${ }^{30}$.

Równie drobiazgowo, jak program nauczania i plan lekcji, zaplanowany został rozkład dnia ucznia. Pobudka była o godz. 5 rano, pół godziny przewidziano na umycie się i ubranie, 15 minut na poranny pacierz. Od godz. 5.45 do 6.45 był czas na przygotowanie się do lekcji. O godz. 7.00 zaczynała się obowiązkowa półgodzinna msza św., potem śniadanie, a od 8.00 - lekcje z półgodzinną przerwą na obiad. Pomiędzy 4.30 a 5.00 był podwieczorek, potem nauka własna, o 7.00 - kolacja, następnie znów nauka własna, a o 9.00 udanie się na spoczynek ${ }^{31}$.

W Gimnazjum Wołyńskim, późniejszym (od 1819 r.) Liceum w Krzemieńcu, do programu nauczania sukcesywnie włączano przedmioty nadobowiązkowe - np. od 1809 roku uczniowie mogli korzystać z nauki języka angielskiego, bibliologii z bibliografią (wykłady odbywały się w niedziele), a także z lekcji licznych „talentów” (odpłatnie) - rysunku i malarstwa, muzyki, śpiewu, gry na instrumentach, gimnastyki, szermierki, lekcji tańca, czy pływania ${ }^{32}$.

29 X. Hugona Kottataja korrespondencya listowna z Tadeuszem Czackim [...], dz. cyt., t. 2, s. 68-69.

30 E. Danowska, Tadeusz Czacki 1765-1813. Na pograniczu epok i ziem, dz. cyt., s. 309-310.

31 H. Merczyng, Kottataja i Czackiego „Projekt urzqdzenia Gimnazjum Wotyńskiego $i$ wszystkich innych szkót w guberni wotyńskiej, Warszawa 1879, s. $144-145$.

32 A. Szmyt, Gimnazjum i Liceum Wotyńskie w Krzemieńcu w systemie ośriaty Wileńskiego Okręgu Naukowego w latach 1805-1833, dz. cyt., s. 160-161. 
W niedziele odbywało się, niejako poza planem lekcji, nauczanie religii chrześcijańskiej (katolickiej i grekokatolickiej) w wymiarze jednej godziny. Religijne wychowanie uzupełniało codzienne uczestnictwo w mszy świętej i obowiązkowa spowiedź przed Wielkanocą oraz przed egzaminami ${ }^{33}$.

Rok szkolny w krzemienieckiej szkole rozpoczynał się 1 września i trwał zazwyczaj do końca czerwca. Uroczystość zakończenia roku odbywała się jednak później, po zakończeniu popisów, czyli publicznych egzaminów, podczas których najlepsi uczniowie prezentowali zdobytą wiedzę w obecności nauczycieli, władz, rodziców i zebranych okolicznych mieszkańców. Corocznie, wzorem wydawanego drukiem programu nauczania, wydawano też i upowszechniano Materye z nauk, czyli zakres nauczania i konkretne pytania z poszczególnych przedmiotów, na które odpowiadali na forum publicznym - podczas lipcowych popisów - wybrani najlepsi uczniowie. Weźmy jako przykład popisy kończące rok szkolny 1809/1810. Najpierw uczniowie odpowiadali z „nauki chrześcijańskiej”. Oto niektóre pytania: „Źrzódło, obowiązki, pożytki i podział nauki chrześcijańskiej”; „Wiara o Bogu; tudzież o stworzeniu człowieka i grzechu pierworodnym"; "Związek nauki obyczajowej, czyli moralnej z nauką chrześcijańską”. Następnie podano zakres tematyki z języka polskiego i łacińskiego z podziałem na poszczególne cztery klasy. Kolejna tematyka to język francuski z nauką moralną, język niemiecki i geografia, język rosyjski i arytmetyka. Do popisów stawali też uczniowie starsi - kursowi, prezentując zdobyte wiadomości. Uczniowie kończący kurs pierwszy byli odpytywani z geometrii elementarnej, trygonometrii płaskiej, geometrii praktycznej, algebry, logiki (do dwóch ostatnich przedmiotów podano konkretne pytania), następnie podano zagadnienia z nauki o wymowie, geografii i historii nowożytnej. Uczniowie kończący kurs drugi odpowiadali z fizyki, geografii fizycznej, geometrii linii krzywych, nauki prawa przyrodzonego, a uczniowie po trzecim kursie odpowiadali z chemii, historii naturalnej, botaniki, literatury i prawa cywilnego. Uczniowie, którzy wybrali dodatkowe przedmioty, byli w 1810 roku egzaminowani z geografii starożytnych Greków i Rzymian, „Declamation poesie et eloquence Française”, języka

33 J. Chodakowska, Gimnazjum i Liceum Wotyńskie w Krzemieńcu (1805-1832), dz. cyt., s. 23. 
greckiego i literatury greckiej, literatury rosyjskiej, mechaniki praktycznej, języka angielskiego i nauki rysunków. Tak wyglądał zakres popisów publicznych w $1810 \mathrm{roku}^{34}$. Inne wydawane drukiem popisy powielały ten schemat, różniąc się jedynie w szczegółach ${ }^{35}$.

Zazwyczaj dopiero od 20 lipca zaczynały się wakacje, a co ciekawe, Czacki był zdania, że uczniowie nawet na ten czas powinni zostawać w szkole. Tadeusz Czacki w swej mowie na zakończenie pierwszego roku szkolnego w Gimnazjum Wołyńskim dokonał analizy korzyści wypływających z wychowania i kształcenia publicznego - w szkołach, a nie w domach ${ }^{36}$. W trakcie roku szkolnego uczniowie mieli tylko krótkie przerwy na Boże Narodzenie i Wielkanoc. Aby zmobilizować uczniów do systematycznej pracy, co pół roku lub co kwartał odbywały się egzaminy ${ }^{37}$. Czacki bardzo dbał o to, by uczeń miał zapewnioną całodzienną opiekę i nadzór starszych. Za bardziej korzystne niż zgromadzenie młodzieży w bursie uważał zamieszkiwanie w prywatnych domach, czyli w tzw. konwiktach, po kilku chłopców. Koszty utrzymania dla najuboższych były finansowane przez rządowe dotacje i ofiary obywatelskie ${ }^{38}$.

Do poszczególnych klas przypisani byli korepetytorzy, mając za zadanie odpytywać uczniów z materiału, który powinni opanować, pełniąc też nad nimi bezpośredni nadzór ${ }^{39}$.

Uczniów szkoły w Krzemieńcu obowiązywał regulamin. Uczniowie czterech początkowych klas podlegali dozorcy, z reguły starsze$\mathrm{mu}$ chłopcu, stanowiącemu w szkole najniższą władzę. Uczniowie nie mogli brać niczego na kredyt, powinni rozliczać się z wydatków

34 Materye z nauk w Gymnazium Wotyńskiem przez przeciag roku szkolnego wytożonych na popisy publiczne uczniórw tegoż Gymnazium w miesiqcu lipcu 1810 porzqdkiem klass i kursów wystawione, b. d. i. m. wyd., nlb.

35 Zob.: Bibliografia polska. XIX stólecie, oprac. K. Estreicher, Kraków 1876, t. 3, s. 83 .

36 T. Czacki, Mowa [...] o pożytkach z wychowania publicznego i domowego przy kończeniu roku szkolnego w Gimnazyum Wotyńskiem miana 1806 roku, 20 lipca, b. d. i m., nlb.

37 A. Szmyt, Gimnazjum i Liceum Wotyńskie w Krzemieńcu w systemie oświaty Wileńskiego Okregu Naukowego w latach 1805-1833, dz. cyt., s. 163-164.

38 E. Danowska, Życie codzienne w Gimnazjum Wotyńskim (1805-1831), dz. cyt., s. 147-150, taż, Tadeusz Czacki 1765-1813. Na pograniczu epok $i$ ziem, dz. cyt., s. 316.

39 A. Szmyt, Gimnazjum i Liceum Wotyńskie w Krzemieńcu w systemie ośrwiaty Wileńskiego Okręgu Naukowego w latach 1805-1833, dz. cyt., s. 159. 
przed rodzicami, pod żadnym pozorem nie wolno było wagarować czy posiadać „broni ognistej”. Występek stanowiła gra w karty, warcaby i loterię. Nie można było trzymać na stancji psów, kotów czy ptaków, „kurzyć tytuniu”, a tabakę wolno było zażywać tylko na podstawie zaświadczenia od lekarza. Bez opieki ze strony nauczyciela czy dozorcy nie można było robić samodzielnych wycieczek. Piętnowane były takie wady, jak niepunktualność, zaniedbywanie obowiązków, lenistwo i rozrzutnośćc ${ }^{40}$.

Istotnym elementem wychowania w placówce krzemienieckiej były sądy uczniowskie - instytucja zaprowadzona przez Tadeusza Czackiego, pomimo sprzeciwu Kołłątaja. Sąd odnosił się jedynie do starszych uczniów, tzw. kursowych. Składał się z wybranych uczniów, którzy rozstrzygali koleżeńskie spory, normowali relacje i łagodziły konflikty. Sąd chronił też uczniów przed nadmierną surowością nauczycieli. Należy podkreślić, że Czacki był zdecydowanym wrogiem stosowania kar cielesnych, uciekając się do kar zawstydzających uczniów czy apelujących do ich honoru ${ }^{41}$.

Młodzieży starano się też zaszczepić patriotyzm pokrewny późniejszym pozytywistycznym ideałom, daleki od żywienia nadziei na niepodległość poprzez walkę .

Zwierzchność Gimnazjum Wołyńskiego (późniejszego Liceum) dbała, aby nie czyniono różnicy w traktowaniu uczniów biednych i bogatych - wszystkich więc obowiązywały mundury z sukna krajowego, które niwelowały różnice w statusie materialnym. Chroniło to też „od ochoty bawienia się w eleganta” $\mathrm{i}$ utrudniało uczęszczanie do miejsc dla młodzieży niewłaściwych ${ }^{43}$.

40 R. Przybylski, Krzemieniec. Opowieść o rozsqudku zwyciężonych, dz. cyt., s. 72; E. Danowska, Życie codzienne w Gimnazjum Wotyńskim (1805-1831), dz. cyt., s. 151.

41 A. Szmyt, Gimnazjum i Liceum Wotyńskie w Krzemieńcu w systemie oświaty Wileńskiego Okręgu Naukowego w latach 1805-1833, dz. cyt., s. 282. Zob. więcej: A. Kamiński, Samorzqd uczniów w szkotach kuratorium wileńskiego z lat 1804-1812, „Przegląd Historyczno-Oświatowy” 1959, R. 2, s. 79-80.

42 E. Danowska, Życie codzienne w Gimnazjum Wotyńskim (1805-1831), dz. cyt., s. 154.

43 R. Przybylski, Krzemieniec. Opowieść o rozsq̨dku zwyciężonych, dz. cyt., s. 7273; E. Danowska, Życie codzienne w Gimnazjum Wolyńskim (1805-1831), dz. cyt., s. 155. Zob. więcej: U. Makowska, Mundury w Gimnazjum i Liceum Wotyńskim w Krzemieñcu, w: „Ateny Wotyńskie” - między historiq a wspótczesnościq, red. A. Szmyt i H. Stroński, Olsztyn-Krzemieniec 2015, s. 115-140. 
Dla krzemienieckich uczniów stworzono instytucję balu publicznego, nazywanego kasynem. Organizowano je w soboty, by uczeń miał czas do przygotowania się do lekcji. Uczestniczyć w nich mogli uczniowie dobrze wywiązujący się ze swych obowiązków, a podczas zabawy w towarzystwie okolicznych mieszkańców i panien, głównie z pensji pani Anieli Rosienkiewiczowej, nadzorowali ich nauczyciele. Miało to umożliwić uczniom nabycie właściwych manier i towarzyskiego obycia ${ }^{44}$.

\section{Opinie o szkole}

Karol Kaczkowski, uczeń Gimnazjum Wołyńskiego w latach 1805-1815, a po skończeniu studiów w Wilnie krzemieniecki lekarz, podkreślał, że Tadeusz Czacki starał się z młodego pokolenia powierzonych jego opiece Polaków uczynić dobrych obywateli. Zaznaczył, że zakresu nauczanych przedmiotów i dobrze wyposażonych gabinetów naukowych nie powstydziłby się żaden uniwersytet. Dzięki pracy doskonałych nauczycieli, absolwenci tej szkoły zawdzięczający im zdobytą wiedzę i umiejętności zajmowali różnorodne odpowiedzialne stanowiska. Młodzież opuszczająca mury szkoły była ponadto wysportowana, umiejąca tańczyć i właściwie się zachowywać ${ }^{45}$.

$\mathrm{Z}$ drugiej zaś strony wrogowie krzemienieckiej placówki zarzucali jej absolwentom zarozumiałość, pyszałkowatość i nieuctwo, samej zaś szkole blichtr, powierzchowność i brak gruntownej nauki ${ }^{46}$. W tej krytyce mógł być pewien element zgodności z prawdą, gdyż Henryk Cieszkowski, były absolwent szkoły, po latach wspominał w pamiętniku: „Bądź co bądź to pewna, że nie było nic dumniejszego jak krzemieńczanin ze swej szkoły, ze wszystkiego, co się tam działo, słowem ze swego Krzemieńca. I nie ma co mówić, miejsce to wielkie miało wzięcie, wielki rozgłos po całym kraju. Studencka ta buta po większej części na cały wiek przy nim zostawała" ${ }^{\text {"47 }}$.

44 R. Przybylski, Krzemieniec. Opowieś́ o rozsadku zwyciężonych, dz. cyt., s. $102-103$.

45 K. Kaczkowski, Odpowiedź na list pana Kwestarza Somnambula, „Athenaeum" 1845 , t. 4, s. $212-224$.

46 T. Bobrowski, Pamiętnik mego życia, oprac., wstęp i przypisy S. Kieniewicz, Warszawa 1979, t. 1, s. 470-474.

47 H. Cieszkowski, Notatki z mojego życia, Poznań 1873, s. 18. 
Z perspektywy lat równie krytyczny był Gustaw Olizar, który napisał: „Systemat naukowy, o ile teraz sądzić mogę, nie był może z najszczęśliwiej dobranych. Było bowiem wszystkiego po trochu i każdy musiał tę trochę wszystkiego liznąć po trochu! Stąd żadnej specjalności, a wiele fanfaronady i papuziej erudycji. Ale Czackiego całkowicie w tym winić nie należy. W stanie ukształcenia obywatelstwa naszego, biorąc u nich fundusze na ten publiczny zakład, trzeba było prawie okazać, że za swój miły grosz dla swojego potomstwa co niemiara rozumu nakupi1!"48

Cieszkowski przyznawał, iż wyniósł z tej szkoły „paniczostwo”, na które „niebezpiecznie chorował”, bo zrodziło w nim próżnośćc ${ }^{9}$.

Jak napisał Ryszard Przybylski: „Grzech zarozumialstwa nie był wydumany. Absolwenci Liceum miewali doprawdy przesadne mniemanie o swojej wyjątkowości” ${ }^{50}$.

Dowcipną charakterystykę byłego krzemienieckiej placówki podał lekarz, pisarz i pamiętnikarz Stanisław Morawski: „Uczniowie krzemienieccy, tym zdurzeni, ujęci jakimsić esprit de corps [poczucie łączności, solidarności], dobrodusznie z ojcami wyobrazili sobie, że jeden tylko jest punkt błyszczący prawdziwym światłem na kuli ziemskiej i że tym punktem jest Krzemieniec. Że wszystkie całego świata uniwersytetu są przy Krzemieńcu - parafialnymi szkółkami” ${ }^{51}$.

Różne klęski żywiołowe (ostra zima, susza, nieurodzajne lato i powszechny głód oraz epidemia cholery), a przede wszystkim wydarzenia związane z powstaniem listopadowym spowodowały, że ukazem cara Mikołaja I z 21 sierpnia 1831 roku zamknięto polskie zakłady naukowe Wołynia, Podola i Ukrainy. Zamknięto także Liceum Krzemienieckie. Uczniowie tej placówki z sympatią ją wspominali i kultywowali poczucie uczniowskiej wspólnoty, pamiętając

48 G. Olizar, Pamiętniki 1798-1865, Lwów 1892, s. 25. O wspomnieniach krzemienieckich uczniów zob. też: B. Topij-Stempińska, Liceum Krzemienieckie w uczniowskim „kadrze wspomnieñ” zatrzymane, w: „Ateny Wotyńskie”między bistoriq a wspótczesnościa, pod red. A. Szmyta i H. Strońskiego, O1sztyn-Krzemieniec 2015, s. 180-186.

49 H. Cieszkowski, Notatki z mojego życia, dz. cyt., s. 18-25, 76-77.

$50 \quad$ R. Przybylski, Krzemieniec. Opowieść o rozsądku zwyciężonych, dz. cyt., s. 140.

51 S. Morawski, Kilka lat mtodości mojej w Wilnie (1818-1825), oprac. i wstęp A. Czartkowski, H. Mościcki, Warszawa 1959, s. 208. 
o słowach Tadeusza Czackiego, że „nic pod słońcem godniejszego być nie może, jak Krzemieńca uczeñ" ${ }^{52}$.

\section{BIBLIOGRAFIA}

\section{Źródła drukowane}

Bibliografia polska. XIX stólecie, oprac. K. Estreicher, Akademia Umiejętności, Kraków 1876, t. 3.

Bobrowski T., Pamiętnik mego życia, oprac., wstęp i przypisy S. Kieniewicz, Państwowy Instytut Wydawniczy, Warszawa 1979, t. 1.

Cieszkowski H., Notatki z mojego życia, „Tygodnik Wielkopolski”, Poznań 1873.

Czacki T., Mowa [...] o pożytkach z wychowania publicznego i domowego przy kończeniu roku szkolnego w Gimnazyum Wotyńskiem miana 1806 roku, b. d. i m. w.

Kaczkowski K., Odpowiedź na list pana Kwestarza Somnambula, „Athenaeum” 1845, t. 4, wyd. Józef Ignacy Kraszewski.

Materye z nauk w Gymnazium Wotyńskiem przez przeciag roku szkolnego wytożonych na popisy publiczne uczniów tegoż Gymnazium w miesiqcu lipcu 1810 porzadkiem klass $i$ kursów wystawione, b.d. i m. w.

Morawski S., Kilka lat mtodości mojej w Wilnie (1818-1825), oprac. i wstęp A. Czartkowski i H. Mościcki, Państwowy Instytut Wydawniczy, Warszawa 1959.

Olizar G., Pamiętniki 1798-1865, Księgarnia Gubrynowicza i Schmidta, Lwów 1892.

Słowikowski A., Wspomnienia szkoty krzemienieckiej, za: Krzemieniec. Ateny Juliusza Stowackiego, pod red. S. Makowskiego, Biblioteka Narodowa. Towarzystwo Literackie im. Adama Mickiewicza, Warszawa 2004.

Wzór i porządek nauk które na lekcyach publicznych w Gymnazium Wolyńskiem od 1 pazdziernika do ostatnich dni lipca 1806 dawane będa [...], b. d. i m.w.

X. Hugona Kottataja korrespondecya listowna z Tadeuszem Czackim, F. Kojsiewicz, Drukarnia Uniwersytecka, Kraków 1844-1845, t. 1-4.

0 pracowania

Beauvois D., Szkolnictwo polskie na ziemiach literwsko-ruskich 1803-1832, t. II Szkoty podstawowe i średnie, Redakcja Wydawnictw KUL, Lublin 1991.

Bryła P., Organizacya Gimnazyum Krzemienieckiego, w: Sprawozdania Dyrektora c.k. Gimnazyum św. Jacka w Krakowie za rok szkolny 1889,

52 E. Danowska, Po upadku Liceum Krzemienieckiego (1805-1831). Polemiki i wspomnienia, dz. cyt., s. 76-77. 
nakładem Funduszu Naukowego, w drukarni Wł. L. Anczyca i Spółki, Kraków 1889.

Chodakowska J., Gimnazjum i Liceum Wotyńskie w Krzemieńcu (1805-1832), w: Krzemieniec. Ateny Juliusza Stowackiego, pod red. S. Makowskiego, Biblioteka Narodowa. Towarzystwo Literackie im. Adama Mickiewicza, Warszawa 2004.

Danowska E., Drukarnia i księgarnia przyszkolna Gimnazjum Wotyńskiego i Liceum Krzemienieckiego (1811-1832), w: Dziatalnośc instytucji wydawniczych na rzecz oświaty i edukacji w XIX i XX wieku, pod red. I. Michalskiej i G. Michalskiego, Wydawnictwo Uniwersytetu Łódzkiego, Łódź 2014.

Danowska E., Po upadku Liceum Krzemienieckiego (1805-1831). Polemiki i wspomnienia, „Annales Academiae Paedagogicae Cracoviensis”, Folia 57. Studia Historica VII 2008, Wydawnictwo Naukowe Uniwersytetu Pedagogicznego.

Danowska E., Tadeusz Czacki 1765-1813. Na pograniczu epok i ziem, Polska Akademia Umiejętności, Kraków 2006.

Danowska E., Tadeusz Czacki i Hugo Kottataj. Kulisy wspótpracy przy tworzeniu Gimnazjum Wotyńskiego w Krzemieńcu, w: „Ateny Wotyńskie”- między bistoriq a wspótczesnościa, pod red. A. Szmyta i H. Strońskiego, Uniwersytet Warmińsko-Mazurski, Olsztyn-Krzemieniec 2015.

Danowska E., Życie codzienne w Gimnazjum Wotyńskim (1805-1831), „Annales Academiae Paedagogicae Cracoviensis" Folia 17, Studia Historica II 2003, Wydawnictwo Naukowe Uniwersytetu Pedagogicznego.

Kamiński A., Samorząd uczniów w szkotach kuratorium wileńskiego z lat 1804-1812, „Przegląd Historyczno-Oświatowy” 1959, R. 2, Kwartalnik Związku Nauczycielstwa Polskiego.

Kisiel-Dorohinicka C., W stronę Krzemieńca. W poszukiwaniu inspiracji dla wychowania w czasach wspótczesnych, w: „Ateny Wotyńskie” - między historiq a wspótczesnościq, pod red. A. Szmyta i H. Strońskiego, Uniwersytet Warmińsko-Mazurski, Olsztyn-Krzemieniec 2015.

Makowska U., Mundury w Gimnazjum i Liceum Wotyńskim w Krzemieńcu, w: „Ateny Wotyńskie” - między bistoriq a wspótczesnościa, pod red. A. Szmyta i H. Strońskiego, Uniwersytet Warmińsko-Mazurski, Olsztyn-Krzemieniec 2015.

Merczyng H., Kottątaja i Czackiego „Projekt urządzenia Gimnazjum Wotyńskiego i wszystkich innych szkót w guberni wotyńskiej”, Drukarnia J. Ungera, Warszawa 1879.

Piotrowski W., Stownik Krzemieńczan 1805-1832, Naukowe Wydawnictwo Piotrkowskie, Piotrków Trybunalski 2005.

Przybylski R., Krzemieniec. Opowieść o rozsq̨dku zwyciężonych, Wydawnictwo Sic!, Warszawa 2003.

Szmyt A., Gimnazjum i Liceum Wotyńskie w Krzemieńcu w systemie oświaty Wilenskiego Okręgu Naukowego w latach 1805-1833, Uniwersytet Warmińsko-Mazurski, Olsztyn 2009. 
Topij-Stempińska B., Liceum Krzemienieckie w uczniowskim „kadrze wspomnieñ” zatrzymane, w: „Ateny Wotyńskie” - między historiq a wspótczesnościq, pod red. A. Szmyta i H. Strońskiego, Uniwersytet Warmińsko-Mazurski, Olsztyn-Krzemieniec 2015.

\section{ADRES DO KORESPONDENCJI}

Dr hab. Ewa Danowska

Polska Akademia Nauk

Biblioteka Naukowa PAU i PAN

ewa.lidia.danowska@gmail.com 